\title{
PERANCANGAN APLIKASI E-VOTING BERBASIS ANDROID DENGAN TEKNOLOGI FIREBASE (STUDI KASUS : PEMILIHAN KETUA HMP FTI UKSW)
}

\author{
Vania Harianto Putri Tjandra ${ }^{1}$, Nina Setiyawati ${ }^{2}$ \\ ${ }^{1,2}$ Fakultas Teknologi Informasi, Universitas Kristen Satya Wacana Salatiga
}

\section{Article Info:}

Dikirim: 23 Maret 2019

Direvisi: 07 Mei 2019

Diterima: 08 Mei 2019

Tersedia Online: 29 Juni 2019

Penulis Korespondensi: Vania Harianto Putri Tjandra Fakultas Teknologi Informasi, Universitas Kristen Satya Wacana Salatiga, Indonesia

Email:

mvhousedeveloper@gmail.com

\begin{abstract}
Abstrak: Voting adalah metode pengambilan keputusan. Contoh kegiatan voting adalah pemilihan Ketua Himpunan Mahasiswa Program Studi (HMP) Fakultas Teknologi Informasi (FTI) di Universitas Kristen Satya Wacana (UKSW) yang masih dilakukan secara konvensional. Namun, kendala yang terjadi adalah sebagian besar mahasiswa dari setiap program studi tidak dapat menggunakan hak suaranya karena terhalang kegiatan lainnya. Sehingga dibutuhkan suatu sistem yang dapat memudahkan kegiatan voting. Tujuan dari penelitian ini adalah membangun aplikasi voting berbasis mobile android untuk memfasilitasi mahasiswa agar dapat memberikan hak suara hanya dengan menggunakan smartphone Android yang terkoneksi dengan internet. Aplikasi ini menggunakan Teknologi Firebase, yaitu Realtime Database, Authentication dan Cloud Storage. Dari pengujian system yang dilakukan, disimpulkan bahwa sistem bekerja dengan baik pada smart phone Android versi 4.3 (Jelly Bean) hingga versi 9.0 (Pie) dan hasil dari kuesioner Likert Summated Rating Scale (LSR) yaitu aplikasi ini sangat membantu mahasiswa untuk berpartisipasi dalam kegiatan voting.
\end{abstract}

Kata kunci: voting; pemilihan ketua HMP; aplikasi e-voting; android, teknologi firebase.

\begin{abstract}
Voting is one method of making decision. One example of voting is the Election a Leader of student major association in Faculty of Information Technology at Satya Wacana Christian University, which is still done conventionally. However, the problem is most of student can't visit the polling booth to cast their vote because they have other activities. Because that reason, we need a system that can makes voting activities easier. The purpose of this research is to build an e-voting application based on mobile android to facilitate students so they can give their vote only by using an Android smart phone which is connected to the internet. This application implements Firebase Technology, specifically are Realtime Database, Authentication and Cloud Storage. Fron the system testing that has been done, it's concluded that the system can be used well on Android smart phone version 4.3 (Jelly Bean) to version 9.0 (Pie) and the results of the Likert Summated Rating Scale (LSR) questionnaire is this application is very helpful for students to participate in voting activities.
\end{abstract}

Keywords: voting; election a leader of student major association; e-voting application; android; firebase technology. 


\section{PENDAHULUAN}

Himpunan Mahasiswa Program Studi (HMP) di Fakultas Teknologi Informasi (FTI) Universitas Kristen Satya Wacana (UKSW) adalah himpunan mahasiswa yang diutus oleh setiap program studi untuk menjadi wadah bagi mahasiswa yang ingin menyalurkan aspirasi mereka. Dari seluruh anggota HMP yang diutus setiap program studi, dipilih satu anggota HMP untuk menjadi ketua HMP. Hingga 2018, pemilihan ketua HMP di FTI UKSW masih dilakukan dengan cara yang telah disepakati peraturan Lembaga Kemahasiswaan, yaitu dengan musyawarah untuk mufakat. Jika dengan cara tersebut tidak tercapai, maka akan dilakukan lobi. Dan apabila lobi tidak tercapai, maka akan dilakukan voting dengan keputusan sah jika disetujui oleh $1 / 2$ ditambah 1 dari kourum rapat HMP. Dimana seharusnya rapat HMP yang diadakan harus dihadiri oleh seluruh mahasiswa yang terdaftar pada program studi tersebut.

Permasalahan yang sering terjadi pada pemilihan ketua HMP Fakultas Teknologi Informasi (FTI) hingga periode 2017-2018 adalah sebagian besar mahasiswa pada program studi tersebut tidak dapat menghadiri rapat HMP karena terhalang waktu dan kegiatan yang ada, sehingga pada dasarnya rapat HMP yang dilaksanakan tidak kuorum (tidak lebih dari 1/2 ditambah 1 mahasiswa program studi yang berhubungan). Selain itu, sebagian mahasiswa di FTI kurang mengenal ketua HMP mereka masing-masing. Bahkan banyak juga mahasiswa yang tidak tahu siapa ketua HMP yang terpilih, karena tidak dapat hadir pada saat rapat HMP.

Berdasarkan Standart Operating Procedure (SOP), tidak ada peraturan yang mendasari larangan untuk melakukan voting diluar tempat pemilihan ketua HMP. Selain itu, perijinan dari ketua Senat FTI UKSW periode 2018-2019 menjadi dukungan utama penulis untuk membangun sebuah aplikasi voting berbasis android untuk memfasilitasi kegiatan pemilihan ketua HMP. Aplikasi yang dibangun akan memberikan fasilitas streaming video untuk menonton kegiatan orasi pada saat rapat HMP.

Go-Vote adalah sebuah aplikasi e-voting berbasis android yang memanfaatkan teknologi sehingga user dapat mengakses informasi mengenai kegiatan pemilihan sewaktu-waktu dan dapat melakukan voting melalui mobile tanpa terhalang ruang dan waktu diadakannya sidang pemilihan. Aplikasi ini menggunakan Teknologi Firebase Realtime Database sebagai database, Firebase Authentication untuk mengautentikasi user dan Firebase Cloud Storage sebagai media penyimpanan.

Berdasarkan latar belakang permasalahan yang ada, dilakukan penelitian dengan tujuan untuk membangun aplikasi e-voting Ketua HMP berbasis android dengan implementasi Firebase untuk memudahkan mahasiswa untuk menonton orasi dan turut ambil bagian dalam pemilihan ketua HMP melalui smartphone android yang terkoneksi dengan internet, tanpa terkendala ruang dan waktu. Batasan masalah yang ada dalam penelitian ini yaitu : 1) Penelitian ini dilakukan dengan melihat dan menganalisis permasalahan yang ada di lingkungan FTI UKSW. 2) Pengambilan keputusan pada sistem $e$-voting ini berdasarkan hasil terbanyak dari jumlah vote yang diterima oleh kandidat.

\section{TINJAUAN PUSTAKA}

\subsection{Penelitian Terdahulu}

Terdapat 2 penelitian terdahulu yang membahas perancangan aplikasi e-voting dengan basis mobile android. Penelitian yang pertama adalah penelitian dengan judul "Rancang Bangun Aplikasi E-Voting Berbasis Android". Penelitian ini bertujuan untuk membangun aplikasi voting yang dapat memfasilitasi kegiatan pemilihan ketua organisasi pada Fakultas Teknik di Universitas Tanjungpura, dikarenakan voting yang dilakukan secara konvensional masih memiliki banyak kekurangan. Berdasarkan hasil perhitungan kuesioner dengan Likert Summated Rating (LSR) diperoleh nilai sebesar 1505, dimana aplikasi dinilai berhasil dibangun dan mayoritas responden dapat menerima aplikasi dengan baik, serta aplikasi dapat berjalan dengan baik pada perangkat Android versi 4.3 (Jelly Bean) hingga versi 6.0.1 (Marsmallow) [6].

Penelitian selanjutnya adalah penelitian yang berjudul "Perancangan Aplikasi Voter Berbasis Android Studi Kasus Pemilihan Ketua Himpunan Mahasiswa Jurusan Teknik Elektro Universitas Sam Ratulangi Manado". Permasalahan yang terjadi pada sistem pemilihan secara manual yaitu banyaknya mahasiswa yang tidak bisa hadir dalam memberikan hak suara karena terkendala jadwal kuliah atau kegiatan lainnya. Oleh karena itu, perancangan aplikasi ini dilakukan untuk memudahkan mahasiswa dalam memberikan hak suaranya. Aplikasi ini dirancang dengan menggunakan database MySQL dan server localhost. Dalam penggunaannya, aplikasi ini dinilai bermanfaat dalam kegiatan pemilihan ketua, namun hasil pengambilan suara separuhnya bergantung pada server. Jika server offline, maka aplikasi ini tidak dapat digunakan untuk voting [14].

Pada penelitian ini dirancang aplikasi $e$-voting dengan basis android karena dari kesimpulan pada penelitian sebelumnya diatas, aplikasi dengan basis android sangat memfasilitasi mahasiswa dalam memberikan hak suaranya tanpa terkendala ruang dan waktu, selain itu mudah untuk diakses selama ada jaringan internet. Pemilihan basis android untuk aplikasi e-voting ini diperkuat dengan bukti bahwa penggunaan smartphone android untuk mengakses internet sangatlah populer dikalangan masyarakat termasuk mahasiswa. Berdasarkan data statistik 5 tahun terakhir yang diperoleh dari situs milik The Statistics Portal, pengguna sistem operasi android di Indonesia mencapai angka tertinggi dibandingkan dengan sistem operasi lainnya, yaitu 88.37\% [11] 
dari 184juta pengguna mobile [12]. Sedangkan menurut data dari Asosiasi Penyelenggara Jasa Internet Indonesia (APJII), penggunaan internet dari kalangan mahasiswa merupakan angka tertinggi, yaitu $89 \%$ (18juta jiwa) [2].

Perbedaan yang terdapat pada penelitian ini dan penelitian sebelumnya adalah penggunaan Teknologi Firebase Penelitian ini menggunakan Real-Time Database sebagai database, Authentication untuk mengautentikasi user dan dan Cloud Storage sebagai media penyimpanan. Sedangkan pada penelitian sebelumnya menggunakan MySQL sebagai database dan server localhost.

\subsection{Penelitian Terdahulu}

Voting merupakan sebuah metode pengambilan keputusan dengan cara menyatukan aspirasi untuk mendapatkan jalan keluar terbaik dalam menyelesaikan suatu permasalahan [6]. Voting adalah salah satu fitur penting dalam proses demokrasi. Voting menunjukan ekspresi kekuatan dari rakyat [9]. Sedangkan e-voting merupakan sistem pemilihan dimana data yang diperoleh dicatat, kemudian disimpan dan diproses dalam bentuk elektronik atau informasi digital [13]. E-voting merupakan contoh dari penerapan teknologi informasi yang terus berkembang pesat. Penerapan $e$-voting ini dinilai dapat mengatasi masalah yang timbul dari kegiatan pemilihan umum yang diadakan secara konvensional [3].

Aplikasi yang akan dirancang dan dibangun pada penelitian ini adalah suatu aplikasi $e$-voting dengan basis android yang akan dirancang menggunakan Android Studio. Android Studio merupakan hasil pengembangan dari Eclipse dan menggantikan Eclipse sebagai Integrated Development Environment (IDE) resmi yang disediakan untuk pengembangan aplikasi dengan basis android. Android Studio merupakan aplikasi yang bersifat open source atau gratis [1]. Android Studio memiliki beberapa fitur, antara lain : 1) Project yang ada berbasis pada Gradle Build. 2) Refactory dan maintenance bug tidak memerlukan waktu yang lama. 3) Tools "Lint" yang terdapat pada Android Studio dikalim dapat digunakan untuk memantau kecepatan, kegunaan dan kompatibilitas aplikasi dengan cepat. 4) Proguard And App-signing untuk memperkuat keamanan. 5) Sudah support untuk pengimplementasian Google Cloud Platfrom [5].

Android merupakan sistem operasi untuk smart phone dengan basis linux. Android merupakan platform terbuka untuk para developer yang artinya para pengembang bebas merancang dan membangun aplikasi mereka untuk dijalankan pada sistem operasi Android. Android memiliki 4 karakteristik, antara lain : 1) Terbuka. 2) Semua aplikasi dibangun sama. 3) Memecahkan permasalahan pada aplikasi. 4) Pengembangan suatu aplikasi dapat dilakukan dengan mudah dan cepat [8].

Firebase adalah teknologi Backend as a Service (BaaS) yang disediakan Google untuk memudahkan pengembangan pada aplikasi berbasis web dan mobile. Menurut Firebase, teknologi ini berfungsi untuk menyinkronkan data antar user dan device yang terhubung dalam hitungan milidetik, sehingga user dapat menerima update data terbaru secara otomatis. Realtime Database adalah database dimana data yang disimpan ter-host di cloud dalam bentuk JSON. Authentication adalah teknologi yang berguna untuk memberikan kemudahan pada pembangunan suatu sistem dengan autentikasi yang aman, memberikan solusi untuk identitas end-to-end serta mendukung login menggunakan akun dengan email/password, Google dan media sosial lainnya. Cloud Storage adalah layanan untuk menyimpan objek berupa gambar, audio, video dan konten-konten lainnya. Teknologi ini menambahkan keamanan user pada saat akan melakukan upload dan download suatu file pada aplikasi, tanpa terkendala kualitas jaringannya [4].

\section{METODOLOGI PENELITIAN}

Tahapan yang digunakan untuk penelitian ini adalah Identifikasi Masalah, Studi Literatur, Perancangan Sistem dan Penulisan Artikel Ilmiah, seperti yang terlihat pada Gambar 1.

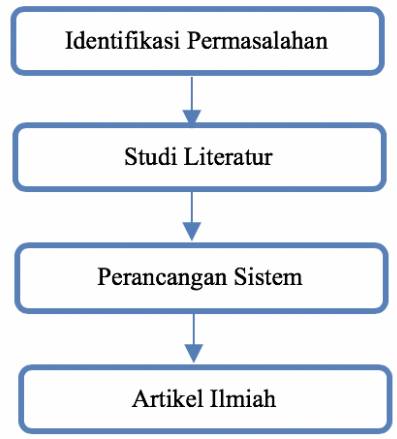

\section{Gambar 1. Tahapan Penelitian}

Mengacu tahapan penelitian pada Gambar 1, dilakukan tahap (1) Identifikasi Permasalahan. Tahap ini dilakukan dengan melakukan analisis dan observasi saat pemilihan ketua HMP di FTI UKSW secara manual. Dan permasalahan yang didapat adalah jumlah pemilih (voter) tidak memenuhi kuorum.

Selanjutnya adalah tahap (2) Studi Literatur yang dilakukan dengan mengumpulkan teori-teori dan jurnaljurnal yang berkaitan dengan data-data penunjang untuk sistem pemilihan (e-voting), tools-tools yang akan 
digunakan dan Firebase. Data yang diperoleh akan menjadi acuan dan landasan teori dalam melakukan penelitian ini.

Kemudian tahap (3) adalah tahap Perancangan Sistem. Metode yang digunakan pada tahap perancangan sistem penelitian ini adalah metode SDLC, yaitu metode Waterfall versi Roger S. Pressman 2001 [7]. Alur perancangan yang akan dilakukan sesuai dengan urutan tahapan dibawah ini.

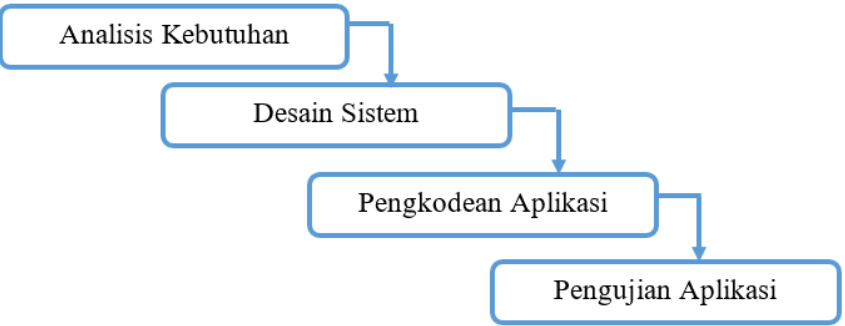

\section{Gambar 2. Metode Waterfall}

Gambar 2 adalah gambar alur perancangan yang dilakukan pada penelitian ini. Tahap (1) Analisis Kebutuhan, yaitu tahap melakukan analisis terhadap data yang dibutuhkan dalam perancangan aplikasi ini. Data diambil secara langsung melalui pendekatan kualitatif (wawancara). Data yang dihasilkan adalah data yang berisikan informasi mengenai kebutuhan user terhadap aplikasi yang akan dibangun, seperti fitur voting, streaming, informasi jadwal, daftar kandidat, informasi kandidat dan visi-misi.

Selanjutnya adalah tahap (2) Desain Sistem, yaitu tahap perancangan desain dari sistem yang akan dibangun berdasarkan hasil analisis kebutuhan dengan menggunakan UML (Unified Modelling Language), yang terdiri dari architecture diagram, activity diagram, use case diagram dan juga class diagram. Tambahan perancangan yang lain yaitu perancangan database dalam bentuk JSON pada Realtime Database, Authentication untuk autentikasi user dan Cloud Storage untuk menyimpan data foto dari kandidat dan user, serta perancangan antarmuka aplikasi yang akan dibuat.

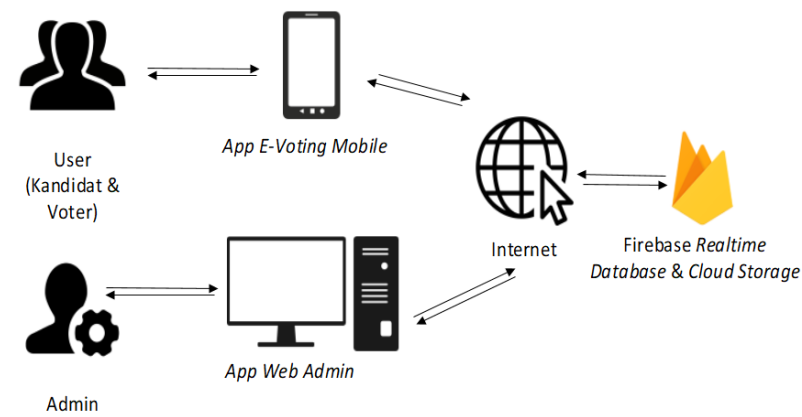

Gambar 3. Diagram Arsitektur

Gambar 3 menunjukan diagram arsitektur sistem dari aplikasi yang dibangun. Pada perancangan ini, Realtime Database, Authentication dan Cloud Storage berperan sebagai back-end service. Web service dari sistem ini menggunakan Firebase REST API. Data akan dikirim melalui Firebase REST API dan dikembalikan ke sistem client untuk ditampilkan menjadi sebuah informasi. Perancangan sistem ini dibangun menggunakan $U M L$ dengan beberapa diagram seperti usecase diagram, class diagram dan activity diagram. Desain use case diagram digunakan untuk memberikan gambaran hubungan interaksi antara aktor dengan sistem yang dibangun [10]. 


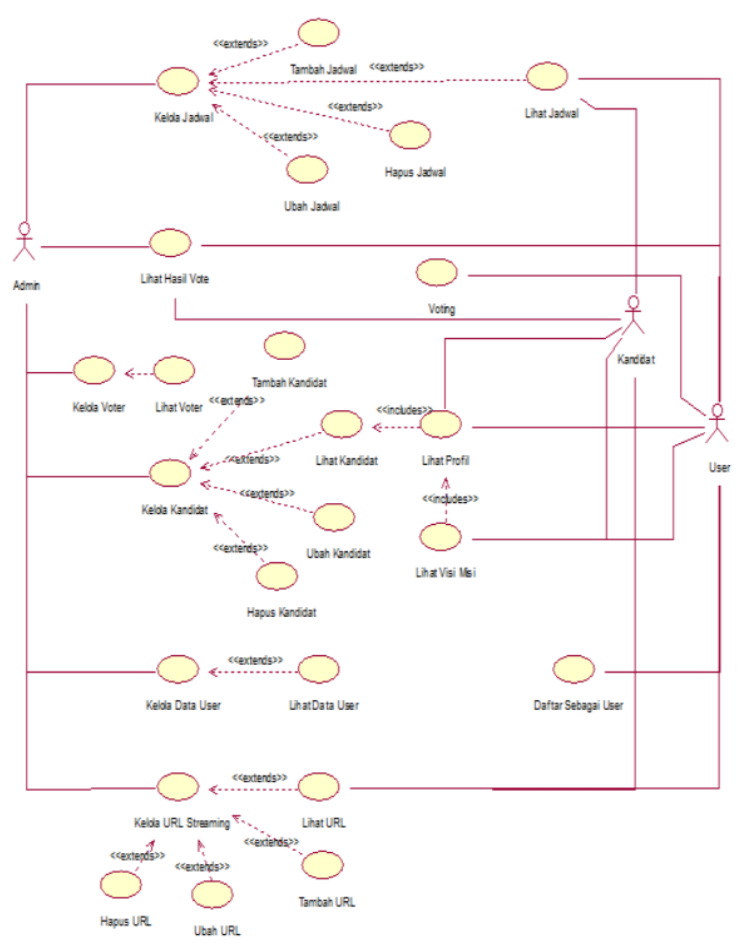

Gambar 4. Use Case Diagram

Terdapat 3 aktor utama pada Gambar 4, yaitu Admin, User (Mahasiswa) dan Kandidat. Mahasiswa dapat mengakses semua menu, yaitu menu Informasi Jadwal, menu Informasi Kandidat, menu Streaming, menu Profil Saya, menu Vote dan menu Hasil Vote. Sedangkan Kandidat dapat mengakses semua menu kecuali menu Vote. Pada menu ini user dapat melakukan voting Ketua HMP. Sedangkan admin hanya dapat melakukan create, update dan delete pada beberapa informasi yang ada seperti informasi Jadwal, Link Video dan Kandidat, serta read pada informasi Mahasiswa dan Hasil Vote.

Activity diagram didesain untuk menggambarkan aktivitas yang terjadi pada sistem, seperti bagaimana setiap alur dimulai, decision yang kemungkinan akan terjadi dan akhir dari alur proses yang terjadi. Diagram mewakili aktivitas setiap aktor dalam menggunakan sistem.

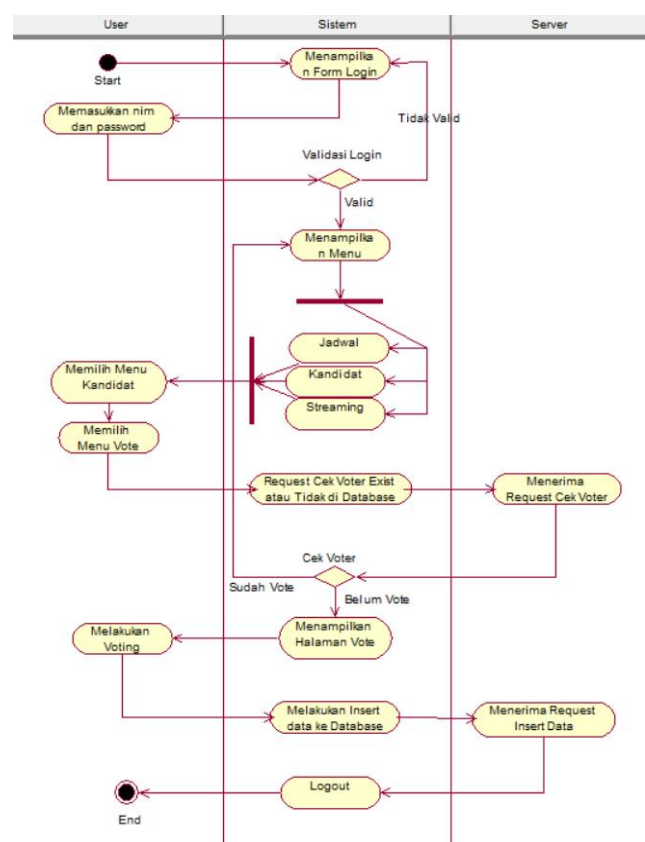

\section{Gambar 5. Activity Diagram Voting}

Gambar 5 menunjukan bahwa user harus login dahulu sebelum masuk ke menu utama. Setelah username dan password valid, maka akan muncul tampilan menu utama sistem. Terdapat menu utama yang akan ditampilkan oleh aplikasi. Setelah memilih salah satu dari menu yang ada, aplikasi akan menampilkan opsi lanjutan untuk dipilih. Opsi saat user melakukan request data ke database akan dikonfirmasi, dimana aplikasi akan terhubung pada web-server. Pertukaran data menggunakan web service merupakan suatu penghubung antara client dan server. Kemudian sistem akan menampilkan data sesuai opsi pilihan. Pada menu utama, 
terdapat pula button logout. Setelah user memilih button ini, maka sistem akan melakukan session destroy dan mengembalikan ke tampilan login.

Class diagram didesain untuk memberikan gambaran mengenai struktur sistem dengan menampilkan class yang memiliki atribut, metode atau operasi, dan hubunganya antar objek [9]. Pada Gambar 6 dibawah, menjelaskan tentang class diagram dari sistem yang dibangun. Sistem ini memiliki control, boundary dan entity. Model berisikan entity yang berguna untuk menangani setiap fungsi yang memiliki hubungan dengan database. Sedangkan View berisikan boundary yang merupakan gambaran tampilan dari sistem yang dibangun. Sedangkan controller berisi control yang berfungsi sebagai jembatan penghubung antara model dan view.

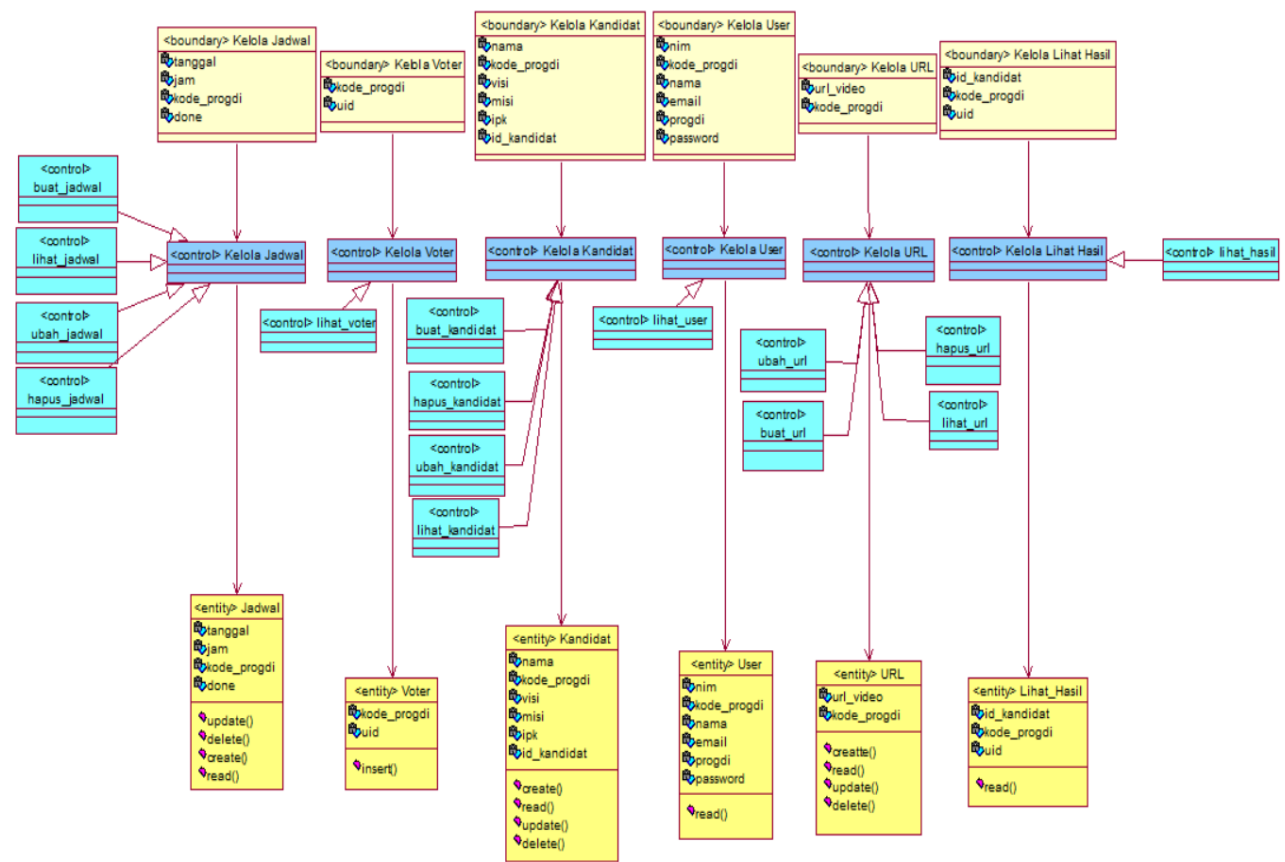

\section{Gambar 6. Class Diagram Sistem Voting}

Tahap selanjutnya adalah tahap (3) Pengkodean Aplikasi, yaitu merancang aplikasi sesuai dengan kebutuhan sistem. Bahasa pemrograman yang digunakan pada perancangan ini adalah bahasa Java yang dirancang menggunakan IDE resmi Android yaitu Android Studio. Aplikasi ini memanfaatkan teknologi Firebase yaitu Realtime Database, Authentication dan Cloud Storage. Selanjutnya tahap (4) Pengujian Sistem yaitu menguji fungsionalitas dari semua fitur yang dalam aplikasi yang dibangun. Dan tahap terakhir dari penelitian ini adalah penulisan Artikel Ilmiah.

\section{HASIL DAN PEMBAHASAN}

Hasil yang diperoleh dari penelitian ini adalah sebuah Aplikasi E-voting Berbasis Android Dengan Teknologi Firebase. Pada proses registrasi, sistem melakukan action pengiriman verifikasi ke email menggunakan Firebase Authentication. Kode Program 1 dan 2 adalah kode program untuk implementasi Firebase Authentication.

\section{Kode Program 1 Implementasi Firebase Authentication Untuk Register}

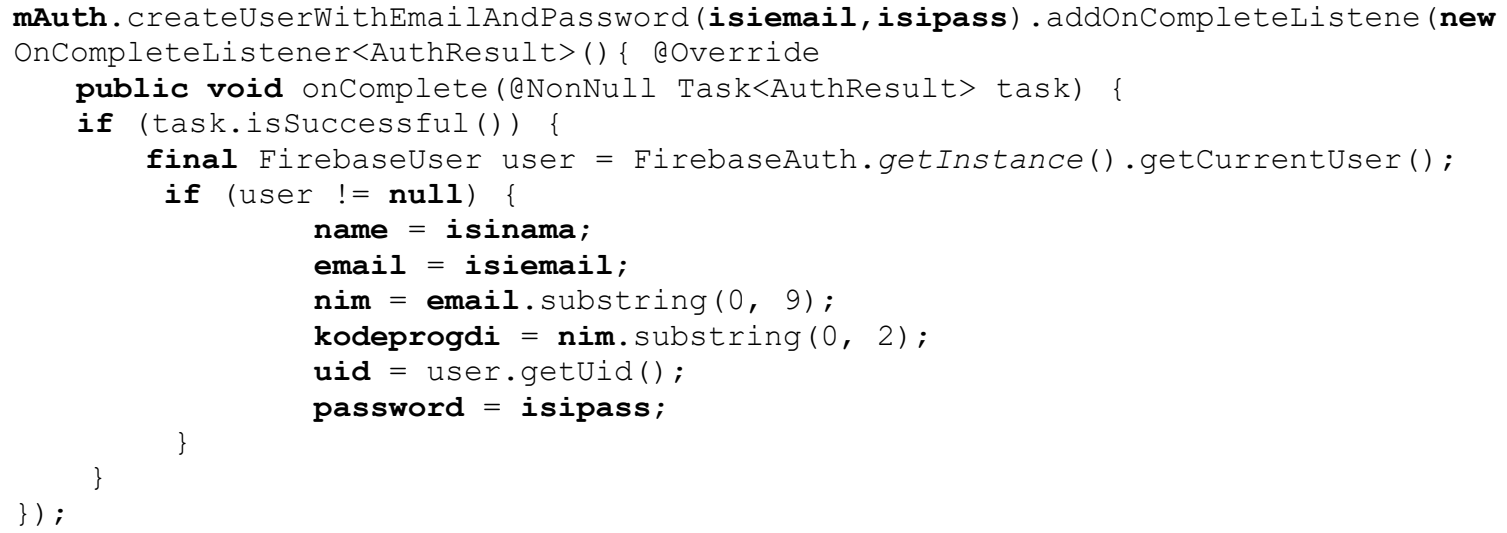

Kode Program 1 adalah kode program implementasi Firebase Authentication yang digunakan untuk registrasi user dengan email student dan password. 


\section{Kode Program 2 Implementasi Firebase Authentication Untuk Register}

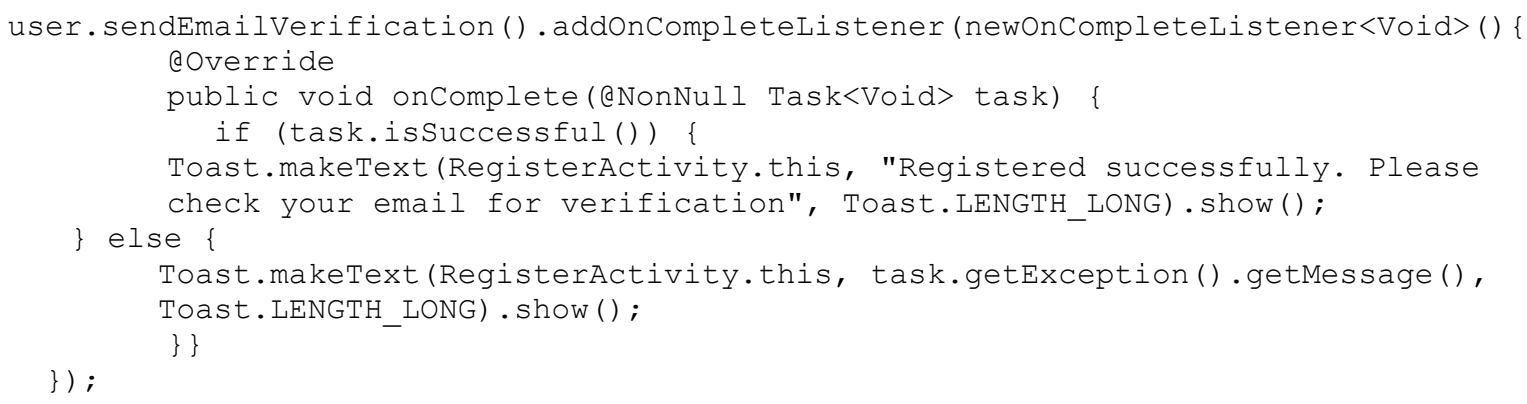

Kode Program 2 adalah kode program implementasi Firebase Authentication yang digunakan untuk mengirimkan email verifikasi kepada user.

User dibedakan menjadi dua, yaitu Mahasiswa dan Kandidat. Mahasiswa dapat mengakses semua menu yang ada, sedangkan Kandidat dapat mengakses menu yang ada kecuali menu Vote. Gambar 7 dibawah ini adalah tampilan dari home screen.

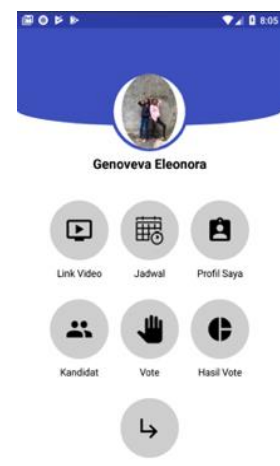

\section{Gambar 7. Tampilan Home Screen}

Aplikasi ini menyediakan informasi seputar kegiatan voting sesuai dengan program studi user, seperti video orasi dari kandidat pada saat rapat sidang, jadwal kegiatan voting yang akan dilaksanakan, informasi dari setiap kandidat dan informasi hasil vote. Aplikasi ini juga menyediakan informasi data diri user dimana user dapat mengubah nama, foto profil dan mengubah password akun, seperti terlihat pada Gambar 8 dibawah ini.

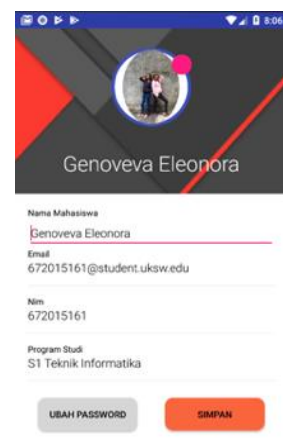

\section{Gambar 8. Tampilan Menu Profil Saya}

Gambar 9 (a) dan (b) dibawah ini adalah menu Kandidat. menu Kandidat ini menampilkan list yang berisikan Nama dan Foto dari para kandidat yang terdaftar sesuai dengan program studi user. Ketika user melakukan click pada salah satu kandidat, maka akan muncul halaman Profil Kandidat yang berisikan informasi Nama, Nim, Program Studi, Quote, Visi dan Misi dari kandidat tersebut. 


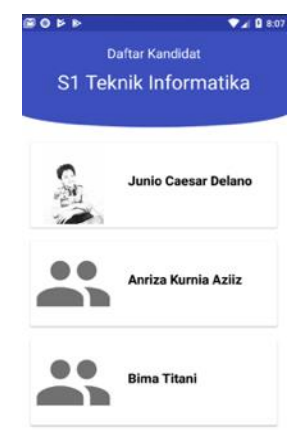

(a)

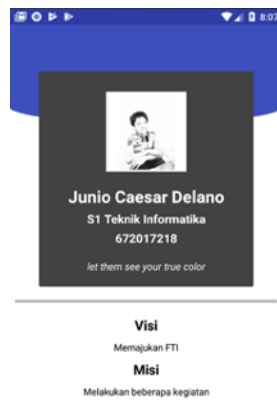

(b)

\section{Gambar 9. (a). Tampilan Menu Kandidat, 9(b). Tampilan Profile Kandidat}

Sistem akan melakukan 3 validate untuk melakukan vote, yaitu validate jadwal, validate user dan validate voter. User tidak dapat melakukan vote jika jadwal tidak sesuai dengan tanggal kegiatan, jika user adalah kandidat dan jika user telah melakukan vote. Validate dilakukan dengan mencocokkan data dari user yang mengakses sistem dengan data yang terdapat di database. Kode Program 3 dibawah adalah contoh fungsi pengambilan data dari realtime database yaitu pengambilan data jadwal.

Kode Program 3 Kode Program Ambil Data Jadwal Dari Firebase Realtime Database

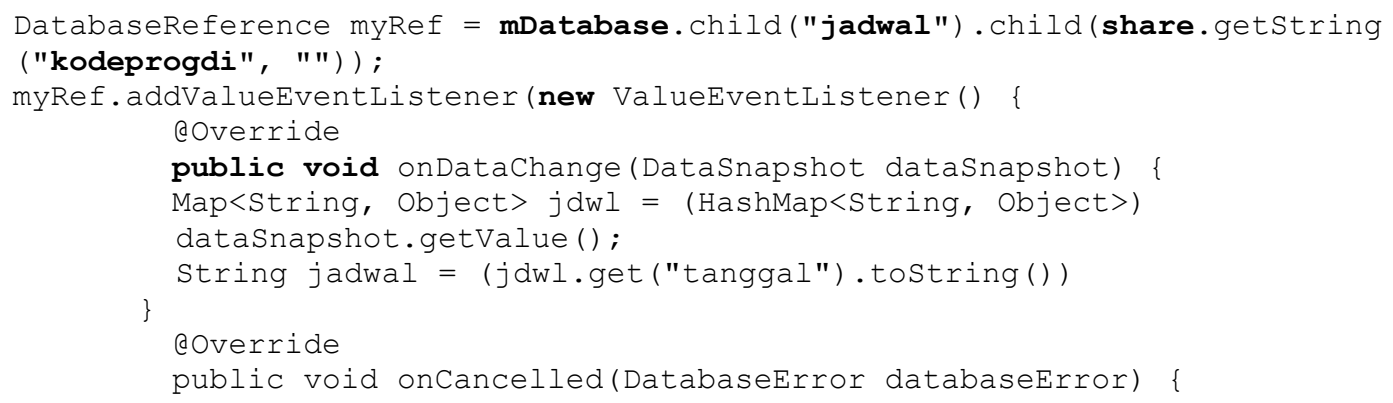

Gambar 10 di bawah ini adalah tampilan halaman Vote yang terdapat list berisikan daftar kandidat. Saat user melakukan vote, sistem akan menambah data NIM user ke tabel allvoter, tabel hasilvote dan akan menambah jumlah voter pada atribut voter di tabel kandidat.

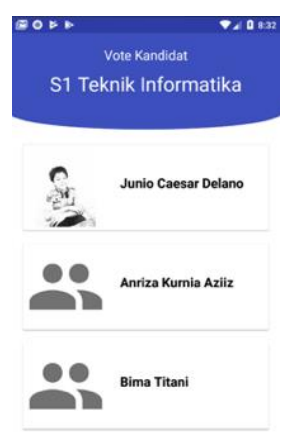

\section{Gambar 10. Tampilan Menu Vote}

Gambar 11 dibawah ini adalah tampilan menu Hasil Vote, dimana akan ditampilkan jumlah voter dari setiap kandidat dalam bentuk pie chart. 


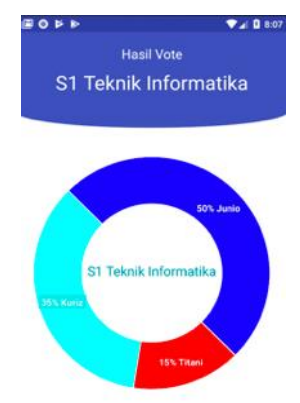

\section{Gambar 11. Tampilan Menu Hasil Vote}

\subsection{Hasil Pengujian}

\subsubsection{Kompatibilitas Aplikasi}

Percobaan uji kompatibilitas dilakukan dengan menginstal dan menjalankan aplikasi pada beberapa smart phone android yang berbeda. Dari hasil uji, diperoleh hasil seperti yang ada di Tabel 1 dibawah ini.

Tabel 1. Hasil uji kompatibilitas terhadap beberapa smartphone android

\begin{tabular}{|c|c|c|c|c|c|}
\hline No & $\begin{array}{c}\text { Nama } \\
\text { Perangkat }\end{array}$ & Layar \& Versi Android & Fungsionalitas & Tampilan & Ket \\
\hline 1 & $\begin{array}{l}\text { Samsung } \\
\text { Galaxy S8+ }\end{array}$ & $\begin{array}{c}\text { Layar : } 6.2 \text { inches; Resolusi : } \\
2.960 \times 1.440 \text { pixel ; Android } 9.0 \text { (Pie) }\end{array}$ & $\begin{array}{l}\text { Fitur Berjalan } \\
\text { Sesuai Fungsi }\end{array}$ & $\begin{array}{l}\text { Ukuran icon tidak } \\
\text { proporsional }\end{array}$ & Sukses \\
\hline 2 & Oppo F1S & $\begin{array}{c}\text { Layar : } 5.5 \text { inches; Resolusi : } \\
1080 \times 720 \text { pixel; Android } 5.1 \\
\text { (Lollipop) }\end{array}$ & $\begin{array}{l}\text { Fitur Berjalan } \\
\text { Sesuai Fungsi }\end{array}$ & Tampilan Sesuai & Sukses \\
\hline 3 & $\begin{array}{l}\text { Xiaomi } \\
\text { Redmi 5A }\end{array}$ & $\begin{array}{c}\text { Layar : } 5.0 \text { inches; Resolusi : } \\
\text { 1.280x1.080 pixel; Android 7.1.2 } \\
\text { (Nougat) }\end{array}$ & $\begin{array}{l}\text { Fitur Berjalan } \\
\text { Sesuai Fungsi }\end{array}$ & Tampilan Sesuai & Sukses \\
\hline 4 & $\begin{array}{l}\text { Samsung J7 } \\
\text { Prime }\end{array}$ & $\begin{array}{c}\text { Layar : } 5.5 \text { inches, Resolusi : } \\
\text { 1.920x1.080 pixel; Android 6.0.1 } \\
\text { (Marshmallow) }\end{array}$ & $\begin{array}{l}\text { Fitur Berjalan } \\
\text { Sesuai Fungsi }\end{array}$ & Tampilan Sesuai & Sukses \\
\hline 5 & $\begin{array}{l}\text { Xiaomi } \\
\text { Redmi 1S }\end{array}$ & $\begin{array}{c}\text { Layar : } 4.7 \text { inches, Resolusi : } \\
\text { 1280x720 pixel; Android } 4.3 \text { (Jelly } \\
\text { Bean) }\end{array}$ & $\begin{array}{l}\text { Fitur Berjalan } \\
\text { Sesuai Fungsi }\end{array}$ & $\begin{array}{l}\text { Ukuran icon tidak } \\
\text { proporsional }\end{array}$ & Sukses \\
\hline
\end{tabular}

Terdapat 2 hal yang menjadi tolak ukur penilaian aplikasi berhasil berjalan pada setiap perangkat mobile dengan platform Android yang berbeda, yaitu : 1) Fungsionalitas. 2) Tampilan Aplikasi. Berdasarkan hasil uji kompabilitas dari aplikasi, menunjukan bahwa aplikasi berhasil berjalan dengan baik pada perangkat Android versi 4.3 (Jelly Bean) hingga versi 9.0 (Pie). Seperti yang terdapat pada Tabel 1, semua fitur berjalan sesuai dengan fungsinya pada setiap perangkat yang diujikan. Namun untuk tampilan pada perangkat dengan ukuran layar 4.7 inches dan 6.2 inches akan menampilkan icon dengan ukuran yang tidak proporsional, sehingga dapat disimpulkan bahwa perbedaan ukuran layar dan ukuran resolusi setiap perangkat mobile mempengaruhi tampilan pada aplikasi. Selain itu, koneksi internet sangat mempengaruhi pengambilan data dari server dan pengiriman data ke server.

\subsubsection{Kuesioner}

Kuesioner merupakan salah satu teknik pengumpulan data yang dilakukan dengan cara memberi beberapa pernyataan atau pertanyaan tertulis kepada sejumlah responden yang merupakan Mahasiswa FTI untuk dijawab. Kuesioner dibagikan kepada 20 responden. Dari hasil kuesioner, diperoleh hasil seperti pada Tabel 2 dibawah ini.

Tabel 2. Hasil kuesioner terhadap 20 responden

\begin{tabular}{|c|c|c|c|c|c|c|c|c|}
\hline No & Pernyataan & 1 & 2 & 3 & 4 & 5 & Total & Hasil \\
\hline 1 & Aplikasi ini sangat mudah digunakan & & & 2 & 13 & 5 & 20 & $93 \%$ \\
\hline 2 & User interface aplikasi ini user friendly & & & 2 & 11 & 7 & 20 & $85 \%$ \\
\hline 3 & $\begin{array}{l}\text { Aplikasi ini memberikan saya informasi terkait } \\
\text { pemilihan Ketua HMP }\end{array}$ & & & 4 & 6 & 10 & 20 & $86 \%$ \\
\hline 4 & Aplikasi ini membantu saya dalam voting Ketua HMP & & & & 4 & 16 & 20 & $96 \%$ \\
\hline
\end{tabular}


Dari interpretasi skor menggunakan skala Likert's Summated Rating (LSR) menunjukan hasil perhitungan untuk pernyataan pertama sebesar 93\%, untuk pernyataan kedua sebesar 85\%, untuk pernyataan ketiga sebesar $86 \%$ dan untuk pernyataan keempat sebesar 96\%. Berdasarkan hasil interpretasi skor tersebut, nilai tertinggi adalah 96\% pada pernyataan keempat yaitu Aplikasi ini membantu dalam voting Ketua HMP, dimana nilai 96\% berada pada interval sangat setuju yang berarti aplikasi dinilai berhasil dibangun untuk membantu Mahasiswa FTI voting Ketua HMP.

\section{KESIMPULAN DAN SARAN}

Berdasarkan hasil pengujian sistem, disimpulkan bahwa aplikasi $e$-voting untuk pemilihan Ketua HMP yang dibangun dengan basis android dan mengimplementasikan Firebase Realtime Database sebagai database, Firebase Authentication sebagai autentikasi user dan Cloud Storage sebagai media penyimpanan, berhasil dirancang dan dibangun dengan baik. Aplikasi ini dapat berjalan dengan lancar pada smartphone Android mulai dari versi 4.3 (Jelly Bean) hingga versi 9.0 (Pie). Selain itu, berdasarkan hasil interpretasi skor dengan skala Likert Summated Rating (LSR) terhadap usability, didapatkan nilai tertinggi $96 \%$ yang berarti bahwa aplikasi yang dibangun dinilai sangat memudahkan mahasiswa untuk berpartisipasi dalam kegiatan voting.

Saran untuk penelitian kedepannya adalah pembangunan aplikasi Hybrid untuk $e$-voting ini. Karena dengan Hybrid, aplikasi dapat dibangun untuk cross-platform dengan cepat.

\section{DAFTAR PUSTAKA}

[1] Android Developer. 2018. Android Studio. Availablehttp://developer.android .com/sdk/. [diakses 7 Februari 2018].

[2] Asosiasi Pengguna Jasa Internet Indonesia. 2018. Data Pengguna Internet Berdasarkan Pekerjaan. Available : https://www. apji.or.id/. [diakses 28 Juli 2018].

[3] De Vuyst, B., dan Fairchild, A., 2005. "Experimenting with Electronic Voting Registration: the Case of Belgium." The Electronic Journal of eGovernment Belgium : Vesalius College, Vrije Universiteit Brussel.

[4] Firebase. 2017 RealTime Database, Authentication and Cloud Storage. Available: https://firebase.google.com. [diakses 9 April 2018].

[5] Juansyah, A., 2015. "Pembangunan Aplikasi Child Tracker Berbasis Assisted-Global Positioning System (A-GPS) Dengan Platform Android”. Bandung. Jurnal Ilmiah Komputer Dan Informatika. 1(1), 8.

[6] Prananda, R., Anra, H., dan Pratiwi, H. S., 2017. "Rancang Bangun Aplikasi E-Voting Berbasis Android (Studi Kasus: Pemilihan Ketua Organiasi Di Lingkungan Fakultas Teknik Universitas Tanjungpura)". Tanjungpura. Universitas Tanjungpura.

[7] Pressman, Roger S., (2001). Software Engineering: A Practitioner's Approach, Fifth Ed. New York : McGraw-Hill Book Company.

[8] Safaat, N., (2011). Android: Pemrograman Aplikasi Mobile Smartphone dan Tablet PC Edisi Revisi. Bandung : Informatika.

[9] Steyn, J., dan Van Greunen, D., 2014. "Designing, developing and testing a mobile phone voting system in the South African context." ICTs for inclusive communities in developing societies. Proceedings of the 8th International Development Informatics Association Conference, held in Port Elizabeth, South Africa. ISBN: 978-0-620-63498-4 Pages 372-385.

[10] Sukamto, Rosa Ariani., dan Shalahudin, M., (2013). Rekayasa Perangkat Lunak Terstruktur dan Berorientasi Objek. Bandung : Informatika.

[11] The Statistics Portal. 2018. Market share of mobile operating systems in Indonesia from January 2012 to 2017. Available:https://www.com/statistics/262205/market-share-held-by-mobile-operating-systems-in-indonesia/. [diakses 27 Juli 2018].

[12] The Statistics Portal. 2018. Number of mobile phone users in Indonesia from 2013 to 2019 (in millions). Available: https://www.statista.com/statistics/274659/forecast-of-mobile-phone-users-in-indonesia/. [diakses 27 Juli 2018].

[13] VoteHere Inc. 2002. Network Voting Systems Standards. Public Draft 2. USA.

[14] Warouw, Riske P., Alicia A.E. Sinsuw, ST., MT., dan Xaverius B. N. Najoan, ST., MT., 2014. "Perancangan Aplikasi Voter Berbasis Android Studi Kasus Pemilihan Ketua Himpunan Mahasiswa Jurusan Teknik Elektro Universitas Sam Ratulangi Manado”. Teknik Elektro dan Komputer Universitas Sam Ratulangi Manado. 